\title{
Menilai Tingkat Religiusitas dan Pengetahuan pada Perilaku Beli Generasi Muda Terhadap Produk Pangan Halal Nurwulan Purnasari ${ }^{1}$, Fuad Hasyim ${ }^{1}$, Iman Sabarisman ${ }^{2}$ \\ ${ }^{1}$ IAIN Surakarta \\ 2 Universitas Gadjah Mada
}

e-mail: nurwulan.purnasari@yahoo.com

\begin{abstract}
Halal food products are a necessity for a Muslim. However, not all food circulating in the market is halal products, so people must be smart in choosing food products. This study aims to determine the relationship between knowledge and the level of religiosity of young people towards the decision to buy halal food products. Based on the sample of young people from various universities in the Yogyakarta and Surakarta areas the results showed that the level of religiosity and knowledge about halal food products had an influence on purchasing decisions for halal products, except that the level of religiosity had a higher influence. This shows that the level of religiosity is an important factor that needs to be considered especially in promoting halal food products.
\end{abstract}

Keywords: halal food products, young generation, level of religiosity, knowledge, buying decisions

\section{A. PENDAhUluAN}

Produk pangan halal menjadi sebuah kebutuhan bagi seorang muslim. Dengan bertambahnya jumlah penduduk muslim maka kebutuhan akan produk halal pun akan bertambah. Generasi muda menjadi salah satu penyebab munculnya trend baru dalam perilaku di kalangan muslim, hal ini disebabkan karena mulai tumbuhnya sikap waspada di kalangan mereka (Swidi, 2010). Generasi muda Muslim mulai paham kebutuhan untuk menghindari segala produk turunan yang melibatkan produk haram seperti babi dan alkohol serta darah, hal ini yang mendorong munculnya produk halal di semua aspek kehidupan manusia, dari mulai produk makanan, kosmetik, toileters hingga personal care products. Fenomena ini menuntut produsen produk untuk mencari sertifikat halal guna merebut pasar. Yousef (2008) menyebutkan bahwa konsumen yang menggunakan produk halal akan selalu loyal membeli produk-produk berlabel halal dan kecenderungan ini semakin meningkat.

Berbicara tentang produk halal maka tidak hanya terbatas pada produk pangan, namun juga produk-produk harian yang terdiri dari produk kosmetik, farmasi, peralatan rumah tangga dan toileters. Mengacu pada data dari State the Global Islamic Economy 2014-2015 yang dikeluarkan oelh Thomson Reuters dan Dinar standart disebutkan bahwa indikator tren bisnis halal mengalami peningkatan pada 5 bidang industri diantaranya jasa keuangan islami, makanan halal, busanan muslim, media dan wisata halal serta farmasi dan kosmetik halal.

Gaya hidup halal dewasa ini telah menjadi pilihan tidak hanya di negara mayoritas muslim juga negara perpenduduk mayoritas non muslim. Begitu pula yang dikatakan oleh Horndby, et.al (2009) yang menyebutkan bahwa konsumen non muslim Eropa justru 
memilih produk halal karena menurut mereka produk halal lebih terjamin keamanan serta kebersihannya. Tingkat konsumsi masyarakat muslim dunia terhadap produk makanan dan minuman halal tahun 2013 telah mengalami peningkatan 10,8\% dibanding tahun sebelumnya dengan total nilai US\$ 1,29 miliar. Diperkirakan pada tahun 2019 nilainya akan mencapai US\$2,54 miliar, setara dengan 21,2\% dari jumlah total konsumsi dunia (Warta Ekspor, 2015). Untuk produk farmasi dan kosmetik, diperkirakan pada tahun 2019 konsumsi terhadap kedua produk ini tang tidak mengandung bahan-bahan haram yang dilarang oleh Al-Quran dan Hadist akan mencapai US\$ 72 Milyar atau setara dengan 6,6\% dari total konsumsi dunia.

Maryam (2013) menjelaskan bahwa adanya hubungan antara tingkat religiusitas dengan perilaku konsumsi, dimana konsumsi produk halal meningkat seiring dengan tingkat pemahaman agama. Di Indonesia, kebutuhan atas produk halal merupakan hasil dari keyakinan terhadap agama demi menjaga kualitas hidup dan kehidupan. Seperti tercantum pada Warta Ekspor edisi Juli 2015, Sebagai negara berpenduduk muslim terbesar didunia ( $87 \%$ dari 217 juta jiwa) maka penting untuk memastikan peredaran produk yang aman dan berstandar halal. Bagi muslim, menggunakan produk halal merupakan persoalan penting karena adanya tuntuan agama, terutama karena halal merupakan penentu diterima atau tidaknya ibadah seseorang.

Hal ini juga merupakan hak sebagai warganegara yang dijamin oleh Undang-Undang Dasar 1945 khususnya Undang-Undang Perlindungan Konsumen No. 8 Th 1999 (Tambunan, 2013). Seperti juga yang disampaikan Soesilowati (2010) dimana konsumen di daerah mayoritas muslim (Banten, Jawa Barat) menempatkan status halal menjadi faktor utama dalam memilih produk. Hadirnya UU Jaminan Produk Halal merupakan representasi dari tanggungjawab negara dalam memberikan perlindungan dan rasa aman dalam mengkonsumsi/ menggunakan produk yang sesuai syariat yaitu halal dan thoyib (Juwaini, 2012).

Perkembangan teknologi telah melahirkan perubahan dalam produksi produk baik produk pangan maupun non pangan. Produsen selaku penyedia barang dan jasa memanfaatkan berbagai bentuk teknolosi untuk melakukan produksi sesuai dengan perkembangan zaman. Proses pengolahan yang semakin kompleks dimulai dari pengadaan bahan baku dan bahan tambahan, proses pengolahan, pengemasan dan pengepakan hingga distribusi dan proses penjualan menjadikan akses komunikasi antara konsumen dengan produsen menjadi jauh, dan sulit untuk mengetahui status kehalalan dari sebuah produk. Produsen sebagai pelaku usaha tentunya ingin memperoleh laba sebesar-besarnya ditengah ketatnya persaingan usaha, sedangkan disisi lain konsumen menghendaki produk yang bermutu dengan harga yang relatif terjangkau.

Adanya jurang komunikasi ini bisa menjadi celah yang merugikan bagi konsumen, jika produsen menggunakan produk-produk yang tidak halal guna menekan biaya produksi maupun untuk meningkatkan laba penjualan. Ditambah lagi, disetiap proses pengolahan terdapat titik kritis yang menentukan status halal dan haram suatu produk. Penentuan titik kritis penting dilakukan mengacu pada pedoman halal dari masing-masing perusahaan yang mengacu pada bahan baku yang digunakan selama produksi serta tahapan proses yang berpengaruh terhadap status haram halal suatu produk (Hasan, 2014).

Kedudukan konsumen terhadap produsen produk pada umumnya relatif lemah. Konsumen menjadi objek dari aktivitas bisnis melalui promosi, ikan dan penjualan serta penerapan perjanjian standar yang acapkali merugikan konsumen. Sertifikasi halal yang 
selama ini dilakukan oleh Majelis Ulama Indonesia melalui Lembaga Pengkajian Pangan, Obat-Obatan dan Kosmetika (LPPOM) dengan Komisi Fatwa dan labelisasi Halal yang dikelolah Oleh Badan Pengawas Obat dan Makanan (BPOM) telah memberikan jaminan perlindungan dan kepastian hukum. Hal ini dikarenakan proses panjang yang melibatkan Sistem Jaminan Halal (SJH) oleh perusahaan dan audit oleh LPPOM dan fatwa yang dikeluarkan oleh Komisi Fatwa berdasarkan fakta dilapangan. Penerapan Undang-undang Jaminan Produk Halal oleh pemerintah akan menjadi jawaban keresahan masyarakat, yang awalnya sertifikasi hanya bersifat voluntary (sukarela) menjadi bersifat mandatory (kewajiban) bagi semua produsen terutama produk pangan, obat dan kosmetik serta produk-produk impor.

Nantinya produsen waji mencantumkan sertifikasi halal dari otoritas dalam hal ini Badan Penyelenggara Jaminan Produk Halal (BPJPH). Produsen bertanggung jawab terhadap produk yang diedarkan, dan masyarakat mempunyai hak untuk memperoleh informasi yang jelas mengenai produk yang beredar. Sediktinya ada delapan jenis informasi yang bisa diketahui konsumen dari label kemasan, dalam hal ini kemasan produk pangan, yaitu sertifikasi halal, nama produk, informasi gizi, tanggal kadaluarsa, identifikasi asal produk, berat dan kandungan isi serta tanda-tanda kualitas lainnya. Informasi ini penting diperhatikan oleh masyarakat agar tidak salah beli.

Dalam Theory of Planned Behaviour disebutkan bahwa perilaku konsumsi merupakan hasil dari proses kognisi dimana sikap, persepsi kendali perilaku dan norma subjektif memiliki pengaruh terhadap keputusan dalam membeli sebuah produk. Norma subjektif merupakan persepsi individu atas lingkungan yang berperan penting bagi dirinya terhadap persepsi sebuah objek. Dengan kata lain lingkungan terdekat seperti orang tua, rekan kuliah, sahabat akan berpengaruh terhadap pengetahuan konsumen terkait produk. Kualitas produk, keamanan serta layanan purna jual produk juga merupakan faktor yang menjadi dasar konsumen untuk mengevaluasi produk, sementara atribut berupa harga dan distribusi akan menentukan kemampuan konsumen dalam membeli produk. Hal inilah yang menjadi landasan untuk melakukan penelitian dengan melakukan sampling di lingkungan mahasiswa di daerah Yogyakarta dan Surakarta. Penelitian ini bertujuan untuk mengetahui pengaruh pengetahuan dan tingkat religiusitas di kalangan mahasiswa di daerah Yogyakarta dan Surakarta terhadap keputusan pembelian produk.

\section{B. METODE PENELITIAN}

Subjek pada penelitian ini adalah mahasiswa sebagai perwakilan dari generasi muda di daerah Yogyakarta dan Surakarta yang terdiri dari Perguruan Tinggi non Keagamaan dan Perguruan Tinggi Keagamaan Islam Negeri. Mahasiswa dipilih karena dianggap menjadi kelompok generasi muda yang paling dekat dengan ilmu dan mampu mengakses informasi secara mandiri. Yogyakarta dan Surakarta dipilih karena mempunyai kemiripan di bilang geografis dan budaya sehingga akses pengetahuan mahasiswa di dua wilayah tersebut di anggap seimbang. Jumlah total responden adalah 143 dengan asal universitas dan jurusan yang bervariasi. Model samping yang digunakan adalah random sampling, dengan populasi berupa mahasiswa di kota Yogyakarta dan Surakarta.

\section{Teknik Pengumpulan Data}

Data diperoleh dengan menggunakan kuisoner. Adapun tipe pertanyaannya terbuka dan tertutup. Jumlah pertanyaan yang diajukan adalah 14 pertanyaan dengan 2 pertanyaan tambahan untuk mengkonfirmasi pengetahuan yang dimiliki oleh responden. Pengetahuan terkait produk pangan halal dilihat dari kemampuan 
responden untuk menentukan apakah produk pangan halal disebut halal dari bahan baku saja, dan kemampuan responden untuk mengenali status kehalalan dari produk turunan dari babi, alkohol. Adapun tingkat religiusitas diketahui dari sikap membeli yang memperhatikan logo halal dan memperhatikan fatwa halal MUI dalam membeli produk. Kuisoner di sebar ke beberapa Perguruan Tinggi di area Yogya dan Surakarta.

\section{Teknik Analisis Data}

Analisis data menggunakan analisis regresi berganda dengan regresi logistik untuk mengetahui pengaruh variabel independen (jenis kelamin, asal universitas, pernah belajar di pesantren, dan keikutsertaan dalam halal school) terhadap variabel dependen (pengetahuan tentang kehalalan produk dan keputusan pembelian produk). Analisis regresi logistik mempelajari hubungan antara variabel dependen kategoris dan seperangkat variabel independen (penjelas). Regresi logistik nama digunakan ketika variabel dependen hanya memiliki dua nilai, seperti 0 dan 1 atau Ya dan Tidak. Analisis regresi berganda dan uji hipotesis dilakukan dengan menggunakan Eviews 10. Persamaan regresi berganda dalam penelitian ini yaitu:

$$
\begin{aligned}
& Y=\beta_{1} X_{1}+\beta_{2} X_{2}+\beta_{3} X_{3}+\beta_{4} X_{4}+e_{1} \\
& Z=\beta_{5} X_{1}+\beta_{6} X_{2}+\beta_{7} X_{3}+\beta_{8} X_{4}+e_{2}
\end{aligned}
$$

Keterangan:

$\mathrm{Y}=$ Pengetahuan Tentang Kehalalan Produk Pangan Halal

$\mathrm{Z}=$ Keputusan Pembelian Produk Pangan Halal

$\beta_{1}-\beta_{8}=$ Koefisien Regresi

$\mathrm{X}_{1} \quad=$ Jenis Kelamin

$X_{2}=$ Asal Universitas

$\mathrm{X}_{3} \quad=$ Pernah Belajar di Boarding school (Pesantren)

$\mathrm{X}_{4} \quad=$ Keikutsertaan Halal school (Pelatihan Halal)

$\mathrm{e}_{1}, \mathrm{e}_{2}=$ error (galat)

\section{ANALISA DATA}

Regresi logistik digunakan untuk menganalisis hubungan antara prediktor tunggal, atau beberapa prediktor, dan hasil yang bersifat dikotomi (seperti ada atau tidaknya suatu peristiwa). Bentuk analisis regresi ini telah menjadi alat statistik yang semakin banyak digunakan, terutama selama dua dekade terakhir (Oommen, Baise, \& Vogel, 2011). Ini secara luas dianggap sebagai statistik pilihan untuk situasi di mana terjadinya hasil biner (dikotomi) harus diprediksi (lihat Hosmer \& Lemeshow, 2000; King \& Zeng, 2001). Dalam penelitian ini digunakan 2 konstruk regresi logistik, dimana pada konstruk pertama menggunakan pengetahuan sebagai variabel dependen dan konstruk kedua menggunakan keputusan sebagai variabel dependen. Berdasarkan hasil perhitungan diperoleh hasil konstruk pertama sebagai berikut:

\section{Tabel 1: Hasil Regresi}




\begin{tabular}{|c|c|c|c|c|}
\hline Variable & Coefficient & Std. Error & $\mathrm{t}$-Statistic & Prob. \\
\hline C & 5.080735 & 0.347910 & 14.60357 & 0.0000 \\
\hline GENDER & -0.060041 & 0.382439 & -0.156996 & 0.8755 \\
\hline UNIVERSITIES & -0.390130 & 0.370904 & -1.051835 & 0.2947 \\
\hline BOARDING_SCHOOL & 1.649432 & 0.491102 & 3.358632 & 0.0010 \\
\hline HALAL_SCHOOL & 1.736802 & 0.365914 & 4.746479 & 0.0000 \\
\hline R-squared & 0.228239 & \multicolumn{2}{|c|}{ Mean dependent var } & 5.699301 \\
\hline Adjusted R-squared & 0.205869 & \multicolumn{2}{|c|}{ S.D. dependent var } & 2.239325 \\
\hline S.E. of regression & 1.995553 & \multicolumn{2}{|c|}{ Akaike info criterion } & 4.254059 \\
\hline Sum squared resid & 549.5480 & \multicolumn{2}{|c|}{ Schwarz criterion } & 4.357655 \\
\hline Log likelihood & -299.1652 & \multirow{2}{*}{\multicolumn{2}{|c|}{$\begin{array}{l}\text { Hannan-Quinn criter. } \\
\text { Durbin-Watson stat }\end{array}$}} & 4.296155 \\
\hline F-statistic & 10.20294 & & & 1.622715 \\
\hline Prob(F-statistic) & 0.000000 & \multicolumn{2}{|c|}{ Durbin-Wats on stat } & \\
\hline
\end{tabular}

Hasil perhitungan diatas diperoleh informasi bahwa nilai koefisien determinasi (Adjusted R Square) sebesar 0,205869. Hal tersebut mengindikasikan bahwa 20,5869\% variabel dependen dipengaruhi variabel independen. Kemudian berdasarkan nilai Fstatistic sebesar 10,20294 dengan probabilitas sebesar 0,0000 mengindikasikan bahwa secara simultan variabel independen berpengaruh terhadap variabel dependen. Sementara untuk uji parsial dapat dilihat dari nilai t-statistic dan probabilitasnya. Berdasarkan output diatas diketahui untuk variabel jenis kelamin dan asal kampus diperoleh nilai probabilitas lebih dari 0,05 sehingga dapat disimpulkan bahwa jenis kelamin dan asal kampus tidak berpengaruh signifikan. Sementara untuk variabel pesantren dan kelas halal diperoleh nilai probabilitas kurang dari 0,05 sehingga dapat dismpulkan bahwa pesantren dan kelas halal berpengaruh signifikan terhadap pengetahuan kehalalan produk.

Setelah dilakukan pengujian statistik, kemudian dilakukan uji kelayakan dengan model asumsi klasik, dimana pengujian meliputi uji normalitas, multikolinieritas dan heteroskedastisitas. Adapun hasil output disajikan sebagai berikut:

\section{Grafik 1: Uji Normalitas}

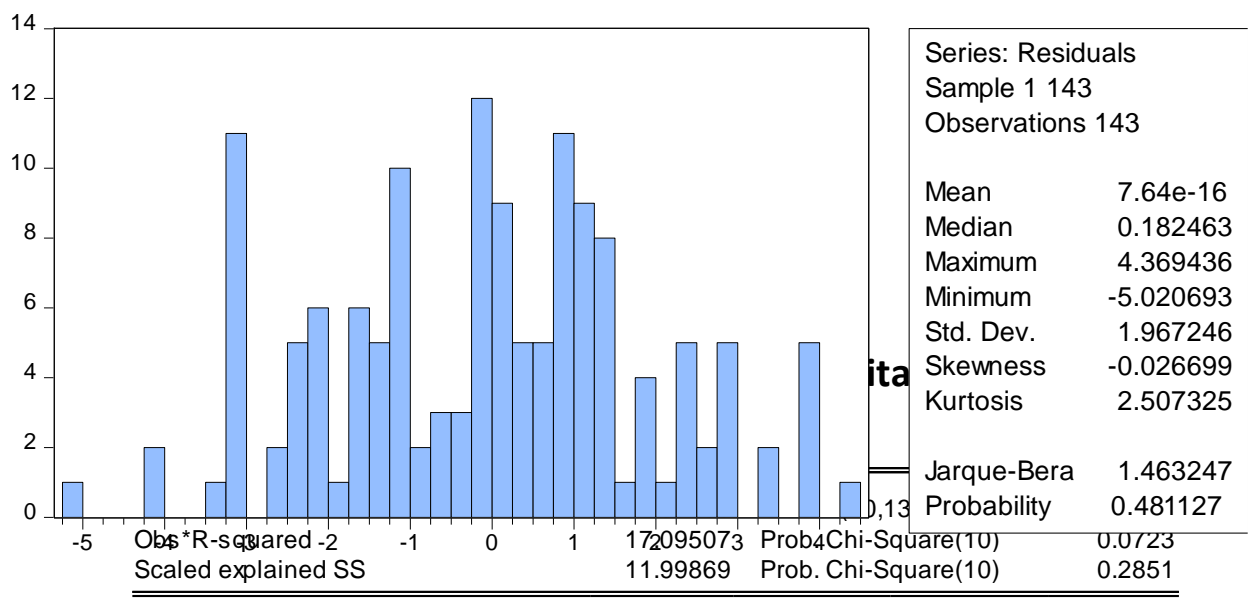

Tabel 3: Uji Multikolinieritas 


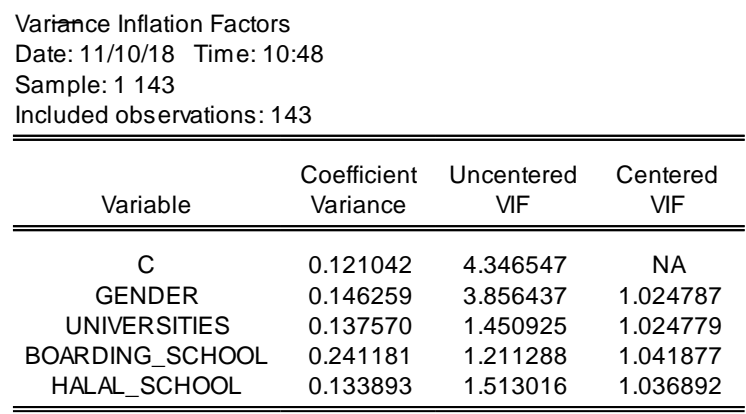

Berdasarkan hasil output diatas diperoleh informasi diatas bahwa aspek asumsi klasik terpenuhi. Pengujian normalitas menggunakan Jarque-Bera dengan probabilitas 0,481127 mengindikasikan tidak bermasalah dengan normalitas karena lebih dari 0,05. Begitu juga dengan uji heteroskedastisitas menggunakan pengujian white test. Hasil diperoleh probabilitas sebesar 0,0723 sehingga data tidak bermasalah dengan uji heteroskesastisitas karena bernilai lebih dari 0,05. Kemudian pada pengujian multiolinieritas diperoleh nilai VIF $<10$, sehingga dapat diasumsikan tidak terkena multikolinieritas. Hasil persamaan regresi dirumuskan sebagai berikut:

$Y=5,08-0,06 X_{1}-0,39 X_{2}+1,65 X_{3}+1,74 X_{4}+e$

Analisa data selanjutnya adalah menggunakan konstruk kedua dengan keputusan sebagai variabel dependennya. Adapun hasil output pengujian diperoleh hasil sebagai berikut:

Tabel 4: Hasil Regresi

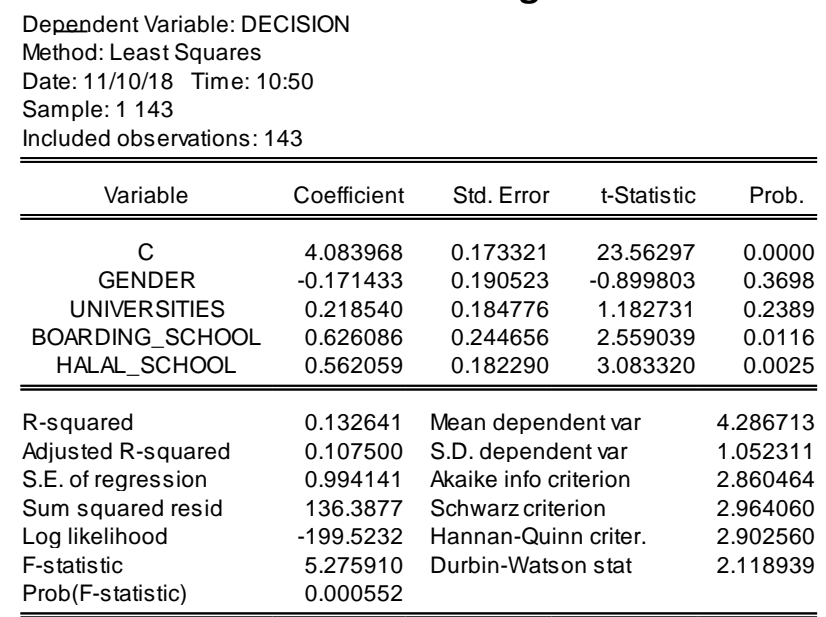

Seperti halnya pengujian sebelumnya, pada bagian ini diperoleh informasi bahwa nilai koefisien determinasi (Adjusted $R$ Square) sebesar 0,107500. Hal tersebut mengindikasikan bahwa 10,75\% variabel dependen dipengaruhi variabel independen. Kemudian berdasarkan nilai F-statistic sebesar 5,275910 dengan Probabilitas sebesar 0,000552 mengindikasikan bahwa secara simultan variabel independen berpengaruh terhadap variabel dependen. Sementara untuk uji parsial dapat dilihat dari nilai tstatistic dan probabilitasnya. Berdasarkan output diatas diketahui untuk variabel jenis kelamin dan asal kampus diperoleh nilai probabilitas lebih dari 0,05 sehingga dapat disimpulkan bahwa jenis kelamin dan asal kampus tidak berpengaruh signifikan. Sementara untuk variabel pesantren dan kelas halal diperoleh nilai probabilitas kurang dari 0,05 sehingga dapat dismpulkan bahwa pesantren dan kelas halal berpengaruh signifikan terhadap keputusan beli produk halal.

Langkah selanjutnya yakni pengujian asumsi klasik, dengan pengujian normalitas, heteroskedastisitas dan multikolinieritas. Adapun hasil output disajikan sebagai berikut: 


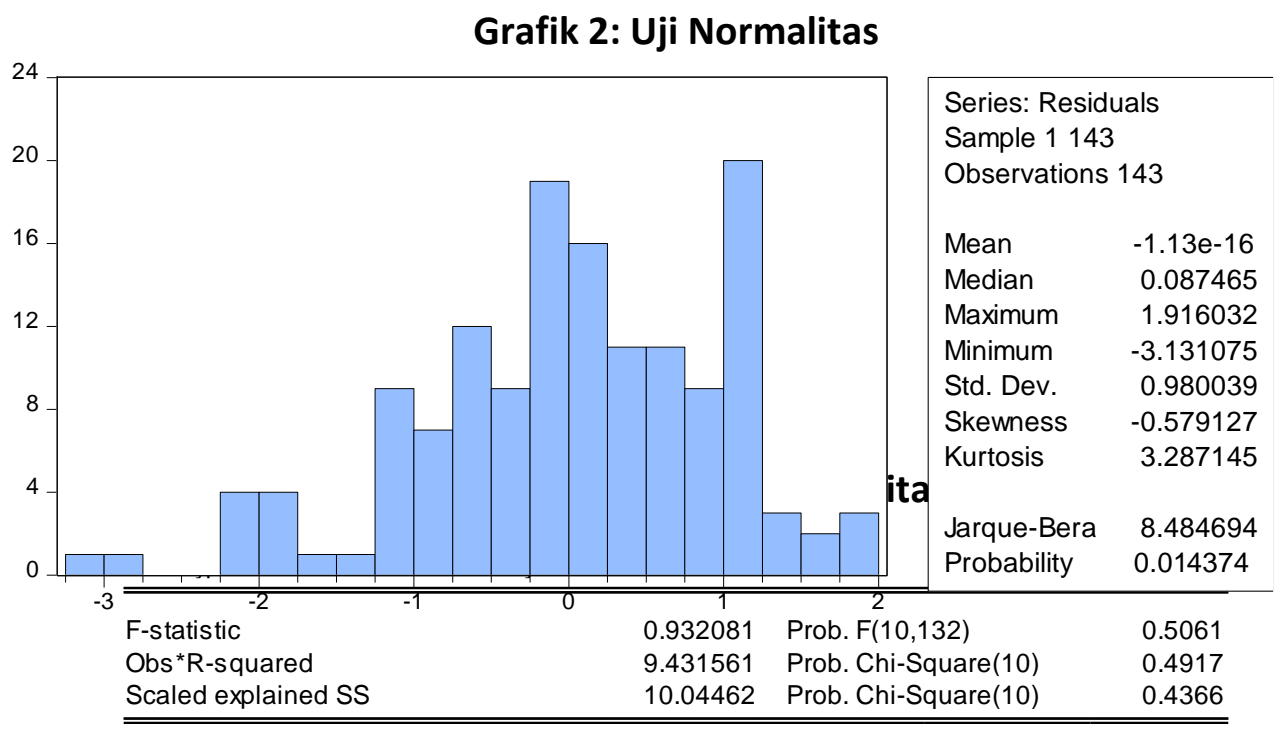

Tabel 6: Uji Multikolinieritas

\begin{tabular}{|c|c|c|c|}
\hline Variable & $\begin{array}{l}\text { Coefficient } \\
\text { Variance }\end{array}$ & $\begin{array}{c}\text { Uncentered } \\
\text { VIF }\end{array}$ & $\begin{array}{l}\text { Centered } \\
\text { VIF }\end{array}$ \\
\hline C & 0.030040 & 4.346547 & NA \\
\hline GENDER & 0.036299 & 3.856437 & 1.024787 \\
\hline UNIVERSITIES & 0.034142 & 1.450925 & 1.024779 \\
\hline BOARDING_SCHOOL & 0.059857 & 1.211288 & 1.041877 \\
\hline HALAL_SCHOOL & 0.033230 & 1.513016 & 1.036892 \\
\hline
\end{tabular}

Berdasarkan hasil output diatas diperoleh informasi diatas bahwa aspek asumsi klasik terpenuhi. Pengujian normalitas menggunakan Jarque-Bera dengan probabilitas 0,014374 mengindikasikan bahwa bermasalah dengan normalitas karena lebih kurang 0,05 . Akan tetapi karena menggunakan sampel jenuh $(n>30)$ dengan menggunakan konsep Central Limit Theorm, maka asumsi normalitas dianggap memenuhi (Gujarati, 2013). Begitu juga dengan uji heteroskedastisitas menggunakan pengujian white test. Hasil diperoleh probabilitas sebesar 0,4917 sehingga data tidak bermasalah dengan uji heteroskesastisitas karena bernilai lebih dari 0,05. Kemudian pada pengujian multiolinieritas diperoleh nilai VIF $<10$, sehingga dapat diasumsikan tidak terkena multikolinieritas. Hasil persamaan regresi dirumuskan sebagai berikut:

$Z=4,08-0,17 X_{1}+0,22 X_{2}+0,63 X_{3}+0,56 X_{4}+e$

\section{PEMBAHASAN}

Tabel 7 memperlihatkan analisis deskriptif dari responden. Responden yang berpartisipasi pada penelitian ini adalah sebanyak 143. Dapat dilihat pada tabel bahwa responden berasal dari Perguruan Tinggi keagamaan dan Non Keagamaan di daerah Yogyakarta dan Surakarta. Adapaun jumlah responden dari Perguruan Tinggi Negeri adalah 21,4\%, dari Perguruan Tinggi Swasta adalah 49,7\%, Perguruan Tinggi Keagamaan Islam adalah $28,9 \%$. Adapaun proporsi responden terdiri dari $26,2 \%$ laki-laki dan $73,8 \%$ perempuan. Dari Seluruh responden ada $31 \%$ yang pernah belajar di boarding school /Pesantren, dan sisanya 69\% menyebutkan tidak pernah belajar di pesantren/boarding school. Dari total mahasiswa yang pernah belajar di pesantren, sebanyak $72 \%$ menyebutkan mereka belajar di pesantren lebih dari 1 tahun. Responden yang pernah 
mengikuti halal school adalah sebanyak $15,2 \%$ sedangkan sisanya mengaku belum pernah mengikuti ataupun mendapatkan pelatihan maupun pembelejaran terkait kehalalan.

Tabel 7: Deskripsi Statistik Responden

\begin{tabular}{llc}
\hline No & Deskripsi & Presentase \\
\hline 1. Gender & Laki-Laki & $26,2 \%$ \\
\hline & Perempuan & $73,8 \%$ \\
\hline 2. Asal Perguruan Tinggi & Perguruan Tinggi Negeri & $21,4 \%$ \\
\hline & Perguruan Tinggi Swasta & $49,7 \%$ \\
\hline & Perguruan Tinggi Keagamaan Islam & $28,9 \%$ \\
& Negeri & \\
\hline 3. Latar Belakang Pendidikan & Boarding School /Pesantren & $31 \%$ \\
\hline & Non Boarding School/ Pesantren & $69 \%$ \\
\hline 4. Keikutsertaan Halal school & Pernah Mengikuti & $15,2 \%$ \\
\hline & Belum Pernah Mengikuti & $84,8 \%$ \\
\hline
\end{tabular}

\section{Tanggapan responden terkait pengetahuan kehalalan produk}

Responden berpendapat bahwa selain bahan baku ada beberapa aspek yang menjadi titik kritis kehalalan pangan. Diantaranya adalah proses pengolahan, sedangkan untuk hewan penyembelihan, titik kritisnya ada pada proses penyembelihannya. Proses pengolahan meliputi aspek bahan baku, alat yang digunakan dan handling proses apakah bercampur dengan yang haram ataukah tidak. Sopa (2008) menyebutkan bahwa yang dimaksud titik kritis kehalalan adalah menelusuri asal mula bahan baku dan proses pengolahannya untuk kemudian dikonsultasikan dengan kaidah hukum Islam yang berkaitan dengan kehalalan. Produk disebut halal jika semua aspek yang bersinggungan telah sesuai, begitu pula sebaliknya. Bila ada ketidaksesuaian maka dilakukan verifikasi.

Titik kritis pengolahan menjadi penting untuk ditentukan dalam sebuah proses sertifikasi produk halal untuk mencegah adanya kesalahan dan penyimpangan dalam proses produksi. QS Al Baqarah :168 memperlihatkan bahwa mengkonsumsi pangan halal tidak hanya ditujukan bagi umat Muslim semata namun umat manusia pada umumnya. Penelitian ini, dalam tanggapannya responden juga menyebutkan bahwa halal tidak hanya kaitannya dengan pangan namun juga beberapa produk lain, diataranya kosmetik, obat-obatan (farmasi) dan toileters serta peralatan rumah tangga.

Berlakunya Undang-Undang Jaminan Produk Halal telah memberikan jaminan tentang keamanan dan kehalalan produk yang tidak hanya terbatas pada produk pangan. UU JPH telah mewajibkan produsen yang mengklaim produknya merupakan produk halal untuk mencantumkan sertifikasi halal dari otoritas yang berlaku, dalam hal ini adalah Badan Penyelenggaran Jaminan Produk Halal (BPJPH) dan peraturan ini nantinya juga akan berlaku bagi produk-produk impor.

Namun perlu dicermati bahwa khusus untuk produk-produk veteriner yang tidak mungkin mendapat sertifikat halal seperti yang sudah ditentukan maka Pemerintah juga tidak mensyaratkan sertifikat halal bagi produk hewan tersebut. Seperti yang diatur dalam Peraturan Menteri Pertanian No 381/ Kpts/OT.140/10/2005 tentang Pedoman Sertifikasi Kontrol Veteriner Unit Usaha Pangan Asal Hewan, produsen produk hewan tidak mewajibkan syarat halal bagi pangan asal babi. Jika produsen memang menggunakan produk turunan babi sebagai salah satu bahan 
bakunya dan mereka mencantumkan informasi tersebut pada label produk pangan yang dihasilkan, maka tidak ada kewajiban untuk melakukan sertifikasi halal. Adanya kejelasan informasi terkait kandungan produk yang bisa diperoleh konsumen dari label produk akan memudahkan kinerja pemerintah dalam mengatur peredaran produk halal. Selain itu juga memberi keleluasaan bagi konsumen untuk memilih produk yang mereka inginkan.

\section{Faktor-faktor yang mempengaruhi pengetahuan tentang kehalalan produk}

Berdasarkan hasil analisis regresi berganda untuk variabel dependen pengetahuan tentang kehalalan produk $(\mathrm{Y})$ diperoleh persamaan sebagai berikut:

$Y=5,08-0,06 X_{1}-0,39 X_{2}+1,65 X_{3}+1,74 X_{4}+e$

Nilai koefisien determinasi $\left(R^{2}\right)$ persamaan tersebut sebesar 0,23 . Hal ini menunjukkan bahwa faktor jenis kelamin, asal universitas, pernah belajar di pesantren, dan keikutsertaan dalam halal school memberikan pengaruh sebesar $23 \%$ terhadap pengetahuan responden tentang kehalalan produk. Sedangkan sisanya sebesar $77 \%$ dipengaruhi oleh faktor lain selain 4 faktor tersebut. Berdasarkan hasil uji hipotesis menggunakan uji $F$, keempat faktor tersebut secara bersama-sama memiliki pengaruh yang signifikan $(p<0,05)$ terhadap pengetahuan responden tentang kehalalan produk.

Uji hipotesis secara parsial ( $u j i \mathrm{t}$ ) terhadap 4 variabel independen memberikan hasil bahwa faktor pernah belajar di pesantren dan keikutsertaan dalam halal school berpengaruh signifikan $(p<0,05)$ terhadap pengetahuan tentang kehalalan produk. Hal ini menunjukkan bahwa sesorang yang pernah belajar di pesantren akan memiliki pengetahuan yang luas tentang kehalalan produk, begitu juga dengan seseorang yang pernah mengikuti halal school. Berdasarkan nilai koefisien persamaan regresinya, terlihat bahwa faktor keikutsertaan halal school bernilai lebih tinggi daripada faktor pernah belajar di pesantren. Artinya faktor keikutsertaan halal school akan lebih besar mempengaruhi pengetahuan seseorang tentang kehalalan produk daripada faktor pernah belajar di pesantren.

Hal ini dapat dipengaruhi oleh materi terkait kehalalan produk yang didapatkan seseorang ketika mengikuti halal school lebih banyak dan terarah dibandingkan dengan materi kehalalan ketika belajar di pesantren. Materi yang diperoleh di pesantren lebih umum dan tidak hanya fokus terhadap materi kehalalan produk. Selain itu perkembangan teknologi memungkinkan adanya perubahan dalam proses pengolahan suatu produk. Pengetahuan yang up to date seiring dengan perkembangan zaman, diimbangi dengan pengetahuan dasar mengenai apa yang boleh dan tidak diperbolehkan dalam agama menjadi faktor yang saling mendukung guna meningkatkan pengetahuan responden terhadap produk halal. Adanya globalisasi memungkinkan terjadi pertukaran teknologi yang memungkinkan hasil produk akhir yang berbeda dari bahan bakunya, hal ini banyak dibahas di materi pelatihan halal maupun halal shcool. Selain itu tersedianya informasi di media massa baik cetak maupun elektronik bisa menjadi penambah wawasan bagi para konsumen, dalam hal ini generasi milenial.

Dua faktor lain yaitu faktor jenis kelamin dan asal universitas tidak berpengaruh signifikan terhadap pengetahuan seseorang tentang kehalalan produk. Artinya baik laki-laki maupun perempuan tidak memiliki pengaruh dengan tingkat pengetahuan mengenai kehalalan produk. Hal ini dimungkinkan, laki-laki maupun perempuan samasama mempunyai tingkat keingintahuan yang sama besar. Selain itu kebutuhan akan 
produk halal yang tidak bergantung pada gender menjadi salah satu latar belakang bahwa baik laki-laki maupun perempunya mempunyai kebutuhan yang sama tentang pengetahuan terkait kehalalan produk

Begitu pula asal universitas juga tidak berpengaruh terhadap pengetahuan tentang kehalalan produk. Responden yang berasal dari Perguruan Tinggi Negeri, maupun Perguruan Tinggi Swasta dan Perguruan Tinggi Keagamaan Negeri samasama mempunyai latar belakang sebagai seorang muslim. Latar belakang inilah yang menjadikan mereka memiliki keingintahuan yang sama besar terhadap informasi sebuah produk halal. Pengetahuan tentang produk halal mejadi sebuah kebutuhan bagi mereka sebagi seorang muslim untuk terhindar dari cemaran produk haram. Karena sebab itulah perbedaan universitas tidak menjadi penyebab tinggi rendahnya pengetahuan yang mereka miliki tentang produk halal. Dengan kata lain jenis kelamin dan asal universitas bukan menjadi penyebab utama seseorang memiliki pengetahuan tentang kehalalan produk.

\section{Faktor-faktor yang mempengaruhi keputusan pembelian produk}

Berdasarkan hasil analisis regresi berganda untuk variabel dependen keputusan pembelian produk (Z) diperoleh persamaan sebagai berikut:

$Z=4,08-0,17 X_{1}+0,22 X_{2}+0,63 X_{3}+0,56 X_{4}+e$

Nilai koefisien determinasi $\left(R^{2}\right)$ persamaan tersebut sebesar 0,13 . Hal ini menunjukkan bahwa faktor jenis kelamin, asal universitas, pernah belajar di pesantren, dan keikutsertaan dalam halal school memberikan pengaruh sebesar $13 \%$ terhadap keputusan seseorang membeli suatu produk. Sedangkan sisanya sebesar 87\% dipengaruhi oleh faktor lain selain 4 faktor tersebut, seperti kualitas produk (Dinawan, 2010), harga produk, lokasi (Ghanimata dan Kamal, 2012), serta citra merek dan promosi (Evelina dk., 2013). Berdasarkan hasil uji hipotesis menggunakan uji F, keempat faktor tersebut secara bersama-sama memiliki pengaruh yang signifikan $(p<$ $0,05)$ terhadap keputusan pembelian produk.

Uji hipotesis secara parsial ( $u j i \mathrm{t}$ ) terhadap 4 variabel independen memberikan hasil bahwa faktor pernah belajar di pesantren dan keikutsertaan dalam halal school berpengaruh signifikan $(p<0,05)$ terhadap keputusan pembelian produk. Hal ini menunjukkan bahwa sesorang yang pernah belajar di pesantren akan mempertimbangkan status kehalalan saat membeli sebuah produk, begitu juga dengan seseorang yang pernah mengikuti halal school. Berdasarkan nilai koefisien persamaan regresinya, berdasarkan koefisien regresi terlihat bahwa faktor keikutsertaan halal school bernilai lebih rendah daripada faktor pernah belajar di pesantren meskipun sama-sama berpengaruh signifikan.

Artinya seseorang yang pernah belajar di pesantren akan lebih berhati-hati ketika membeli produk dibandingkan dengan seseorang yang mendapatkan pengetahuan kehalalan produk dari kegiatan halal school saja. Soesilowati (2010) menyampaikan konsumen di daerah mayoritas muslim (Banten, Jawa Barat) menempatkan status halal menjadi faktor utama dalam memilih produk. Hal ini mendukung hasil penelitian dimana religiusitas dan pengetahuan mengenai produk halal sama-sama berpengaruh terhadap keputusan beli produk halal. Jika ditelisik lebih lanjut, bisa dilihat bahwa sebagian besar responden paham kewajiban sebagai seorang muslim adalah mematuhi norma agama yang berlaku dalam hal ini adalah menghindari produk haram dalam semua aspek kehidupan mereka. 
Selain itu pengetahun mengenai produk halal yang mereka peroleh dari pelatihan halal maupun halal school merupakan bekal penunjang untuk menentukan pembelian atas suatu produk. Informasi yang ada di label produk seringkali tidak selengkap seperti yang diingikan oleh konsumen, maka penting bagi konsumen untuk membekali diri dengan pengetahun mengenai produk yang bisa diperoleh dari berbagai sumber. Adanya campur tangan pemerintah dalam melindungi konsumen dari cemaran produk haram menjadi angin segar bagi peredaran produk halal di Indonesia khususnya. Selain itu pemerintah Indonesia saat ini juga tengah mempersiapkan diri untuk mendukung Indonesia menjadi pusat produk halal dunia, sehingga perlu adanya kerjasama antara produsen, pemerintah dan konsumen dalam mewujudkannya.

Dua faktor lain yaitu faktor jenis kelamin dan asal universitas tidak berpengaruh signifikan terhadap keputusan membeli produk halal. Artinya baik lakilaki maupun perempuan tidak memiliki hubungan dengan keputusan dalam membeli produk. Membeli produk halal bukan merupakan kebutuhan yang didominasi satu gender saja, namun baik laki-laki maupun perempuan sama-sama mempunyai kebutuhan untuk membeli produk halal. Hal ini lebih dikarenakan adanya kesamaan latar belakang agama, sehingga mereka sama-sama berhati-hati dalam menggunakan produk yang diragukan status kehalalannya.

Selain itu hasil ini bisa dipengaruhi dengan tingkat pemahaman mereka terhadap kebutuhan produk halal yang tidak hanya berfokus pada produk pangan saja, namun juga produk-produk non pangan. Begitu pula asal universitas juga tidak berpengaruh terhadap keputusan pembelian produk. Hal ini menjelaskan bahwa responden yang berasala dari Perguruan Tinggi Negeri, perguruan Tinggi Swasta maupun Perguruan Tinggi Keagamaan Negeri mempunyai kebutuhan yang sama untuk membeli produk halal. Dengan kata lain jenis kelamin dan asal universitas tidak menjadi penyebab utama seseorang memutuskan akan membeli atau tidak membeli suatu produk halal.

\section{E. KESIMPULAN}

Dari hasil penelitian dapat disimpulakan bahwa generasi muda yang berasal dari boarding school/pesantren cenderung akan memikirkan status kehalalan dari produk yang mereka beli, begitu pula dengan generasi muda yang pernah mendapatkan pelatihan halal maupun halal school. Sehingga bisa dikatakan bahwa tingkat religiusitas dan pengetahuan mengenai produk halal berpengaruh terhadap keputusan beli produk halal, dimana tingkat religiusitas memiliki pengaruh lebih tinggi. Sedangkan asal universitas maupun gender tidak berpengaruh signifikan terhadap keputusan membeli produk halal, sehingga gender maupun universitas bukan merupakan faktor utama yang menyebabkan seorang generasi muda membeli produk pangan halal atau bukan.

\section{DAFTAR PUSTAKA}

Anonim.2015. Menjadikan Produk Halal Berjaya di Pentas Dunia. Warta Ekspor Edisi Juli

Anonim.2015.Produk Halal di Negara Muslim Terbesar. Metrotvnews [Online]. http://telusur.metrotvnews.com/read/2015/07/24/415252/produk-halal-di-negaramuslim-terbesar 
Dinawan, Rhendria M. 2010. Analisis Faktor-Faktor yang mempengaruhi Keputusan Pembelian (Studi Kasus pada Konsumen Yamaha Mio PT Harpindo Jaya Semarang). Tesis Program MM Undip Semarang.

Erlina N, Handoto Djoko Waloejo, Sari Listyorini. 2013. Pengaruh Citra Merk, Kualitas Produk, Harga dan Promosi Terhadap Keputusan Pembelian Kartu Perdana TELKOMFLEXI (Studi Kasus pada konsumen TelkomFlexi di kecamatan Kota Kudus Kabupaten Kudus). Jurnal Ilmu Administrasi Bisnis Vol.2(1)

Ghanimata, Fifyanita And Kamal , Mustafa (2012) Analisis Pengaruh Harga, Kualitas Produk, Dan Lokasi Terhadap Keputusan Pembelian (Studi Pada Pembeli Produk Bandeng Juwana Elrina Semarang). Undergraduate Thesis, Fakultas Ekonomika Dan Bisnis.

Gujarati, D. N. 2013. Dasar-dasar Ekonometrika, Edisi Kelima. Mangunsong, R. C. penerjemah. Jakarta: Salemba Empat.

Hasan, Sofian KN. 2014. Kepastian Hukum Sertifikasi dan Labelisasi Halal Produk Pangan. Jurnal Dinika Hukum Vol 14 No 2:Palembang.

Hornby C. Yucel S. 2009. Halal Food Going mainstream. Reuters [Online]. http://reuters.com/article/2009/11/17/idINIndia-44025720091117

Hosmer, D. W., \& Lemeshow, S. (2000). Applied logistic regression. New York: John Wiley \& Sons.

King, G., \& Zeng, L. (2001). Explaining rare events in international relations. International Organization, 55, 693-715.

Oommen, T., Baise, L. G., \& Vogel, R. M. (2011). Sampling bias and class imbalance in Maximum-likelihood Logistic Regression. Mathematical Geoscience, 43, 99-120

Juwaini, Jazuli. 2012. UU JOH untuk melindungi Umat. Jurnal Halal no 100 Th XVI: Jakarta.

Sopa, Sopa. 2008. Sertifikasi Halal Majelis Ulama Indonesia: Studi atas Fatwa Halal MUI terhadap Produk Makanan, Obat-obatan dan Kosmetika. Disertasi UIN Syarif Hidayatullah: Jakarta

Swidi, W.C, Hassan, M.G, Hosam, A.A, Kasim,A.W.M. 2010. The Mainstream Cosmetics industry in malaysia and the emergence, growth and prospect of halal cosmetics. Proc. The Third International Conference on International Studies. Hotel Istana Kuala Lumpur: pp-1-20

Tambunan, Amirsyah. 2013. Hak Konsumen dalam Perspektif YY No 8 th 1999. Jurnal Halal No 101 th XVI: Jakarta.

Yousef, D.K. 2010. Halal Food Numbers Look Tasty.Gulf News [Online]. http://gulfnews.com/business/general/halal-food-numbers-look-tasty- 